\title{
Bali Aga Villages in Kintamani, Inventory of Tangible and Intangible Aspects
}

\author{
Ni Made Yudantini \\ Architecture Department \\ Faculty of Engineering, Udayana \\ University \\ Bali, Indonesia \\ nmyudantini@unud.ac.id
}

\begin{abstract}
Indigenous villages in Bali Province is called Bali Aga, which is interesting to do research in depth to understand the indigenous character of Bali Aga. The Bali Aga villages have their own uniqueness for customs, traditions, culture, and architecture and built environment. These characteristics of the uniqueness in Bali Aga villages are defined by the originality of the culture and tradition that are not affected from other culture's influences. Among eight regencies and one city in Bali Province, Bangli Regency has the highest number of Bali Aga villages, which are about 25 villages. Kintamani Sub-district is noted to have approximately 19 Bali Aga villages scattered in the foot of Mount Batur, along Lake Batur, in the north of the Mount Batur and in the mainland or valleys of the Kintamani Sub-district. The other 6 villages are located in Bangli, Susut and Tembuku sub-districts. This research aims to invent the Bali Aga villages in Kintamani Subdistrict for documentation and conservation purposes. This study observed the village including architectural forms of housing typology. The research also aims to understand tangible and intangible aspects of the villages relate to the history, customs, and cultural conditions and architectural of the Bali Aga villages in Kintamani. The research is used a qualitative research method by case study in the Bali Aga villages of Kintamani Sub-district. The case study selected are Suter Village and Abangbatudinding Village due to location and similar in topography. Primary data was collected through observation in the case study area, and interviews to elders and to village's leader. Depth literature review carried out to understand regarding Bali Aga characteristics. The research result to offer guidance and strategies which are not only for academics, also for the community and Bali Government as a basic source of information of Bali Aga village's existence. The research result recommends the villages potential in encouraging identity for their uniqueness of culture, tradition and environment.
\end{abstract}

Keywords: inventory, Bali Aga, Kintamani, tangible and intangible

\section{INTRODUCTION}

The latest research on Bali Aga villages was carried out by Public Works Office, the Government of Bali through the traditional villages (Bali Aga) inventory project from 1988 to 1989. The latest research result was record approximately a number of 38 traditional villages spread in seven regencies of Bali Province. The research illustrated the physical and nonphysical aspects of each of the Bali Aga villages by displaying architectural documentation in an inventory book. The foreign researchers also traced the Bali Aga villages in Bali. For instance, Reuter (2002) who was focus on the highland area in
Sukawana Village. Reuter's research illustrated the rules and Bali Aga traditions called ulu apad. His research is connected to other villages within surrounding the Batur Lake or the Bintang Danu area. Muller's fieldtrip in 1980s documented 25 Bali Aga villages in four areas consisting of the center mountain, the northern coast of Bali, the center of the southern part of Bali and East Bali. Muller as an anthropologist described her research results through the book that published in 2011 which described the villages were faced on the lack of infrastructure, the village's life depend on dry land causing difficulty in rice production. Muller (2011) also sees the villager go to the balian (traditional healer) for traditional medicine. The most important thing of her research in architecture is the spatial orientation of the village using Lake Batur as the direction of the kelod while other Balinese use sea as the orientation of the kelod. She concluded that the water resource was used by the villager as kelod direction. For Balinese people, the direction of the kaja means the North is the primary value that function for holy space where the village's temple is located. Further, the kelod direction means the South for impure zone where usually placed the cemetery and public bathing. Meanwhile the middle zone of the village as a place where the people settle.

However, given that the research of Bali Aga has been carried out for quite a long time (more than 30 years), of course there are many changes that occur in the field, especially changes that occur in the spatial structure of houses in the Bali Aga villages. Until now there has been no institution or group that has done documentation or inventory globally for all Bali Aga villages in the Province of Bali. From the previous research conducted on the existence of Bali Aga villages, there are a number of 62 Bali Aga villages [1] spread across seven regencies in Bali Province, so this research is very important to be done to document the existence of Bali Aga villages in Kintamani Sub-district, considering that Kintamani has the most potential number of Bali Aga villages approximately 19 villages compared to other regions.

The research question is how far the existence of Bali Aga villages in Kintamani still well maintains by the people. How is the characteristic of the traditional housing the Bali Aga in Kintamani and how the people keep the tradition that has been inherited from generation to generation? The research investigated the existence of Bali Aga villages in Kintamani including the intangible and tangible aspects to understand the housing typology and the tradition that has been implemented and maintain until now. 
This research uses a qualitative research method by collecting primary data through observation in the case study area of the Bali Aga villages in Suter and Abangbatudinding villages in Kintamani. Literature study was used that aims to understand the history, the socio-culture, tradition, and the characteristic of the architectural of Bali Aga village. Statistical studies is applied to determine the potential and challenges of the existing villages. The study of previous researches are used to find out the changes that occurred from the past and to compare it to the present. Interviews to the village leader aims to find out the aspect of the tradition is still well maintained considering that the Bali Aga villages as an Indigenous village that still implement the original norms and tradition in their daily life.

\section{UNDERSTANDING OF BALINESE TRADITIONAL Villages of BALi AGA}

\section{A. The Characteristic of Bali Aga}

The word Bali Aga means the mountainous Balinese, where the word aga derives from the word arga, (the Javanese language) means mountain [2]. The understanding of the word Bali Aga revealed by Reuter (2002) that the original Balinese people as 'the mountain Balinese'. The Bali Aga is also called Bali Mula or Bali Kuna [3]. While Covarrubias (1974) states that Bali Aga is 'Bali highland', while Bali Mula means 'the original' and Bali Kuna means 'ancient Balinese' [4]. In this case, this study has an understanding of the Bali Aga, which means the old or traditional villages that are still original retain their customs which are located in mountainous regions, hills, valleys and along of the Batur Lake in Kintamani Sub-district. The Bali Aga villages in question are traditional Balinese villages that still maintain original traditions without influences from the culture during the Majapahit Kingdom power. While the villages that adhere to or accept culture during the Majapahit Kingdom are called the Bali Apanaga Village, where these villages are mostly located in the southern mainland of Bali Island.

There many scholars have been defined the characteristic of Bali Aga. Dwijendra (2009) concludes the characteristics the Bali Aga villages based on the location, the caste system, and the culture that does not influence from the Majapahit era [5].

The characteristics of the Bali Aga villages are as follows. Traditional housing of Bali Aga village consists of twelve pillars called tampul roras or sakaroras. Mostly the houses pattern are linear and are located in a row with no fence between each houses. The linear pattern in one unit housing consists of several sakaroras from five to ten houses. The row of houses creates an orientation of the building or a plaza in the center that functions as circulation. The Bali Aga village adopt ulu apad system for the adat (traditional governance) system. The ulu apad system means 'push to the top' which the elders as a leader is selected based on heredity or natural selection. The Bali Aga people work as farmers and fishermen for the livelihood. The death ceremony is celebrated through cremation (ngaben) ceremony however they don't burn the corpses but cremated through burial system that called biye tanem. They burn the symbols of the death people for the cremation. Most Bali Aga village in Kintamani commemorate mass cremation. The most unique biye tanem system is in Trunyan Village where they buried the death people by putting the corpses on the ground. This unique system called "primitive - sky burial" [3]. The Bali Aga people apply nyineb wangsa system means they do not use the caste on their name. The Bali Aga's names appear as a common people. In fact the Bali Aga people have caste as a pragusti or a knight (ksatria).

The wedding characteristic in the Bali Aga is very unique. The village has a second marriage system that called the ceremony of bakti jauman or pekandelan. The first marriage ceremony called biokaonan that is a simple marriage ceremony in the groom's house. Usually the second marriage commemorate in the village temple of Pura Balai Agung. The bakti jauman ceremony is carried out through mass wedding ceremony where around 40 couple or more joint in this ceremony. The second marriage held if the bride and the groom ready to do the naur kelaci or bakti kelaci by offering pigs or cows to the village. The ceremony naur kelaci aims to inform and complete their status of marriages in the village.

The unique annual festival in the Bali Aga called ngusaba desa. Each village has their own tradition celebrates the ngusaba desa. Example to this is Tengan Village in Karangasem Regency, the village celebrates ngusaba desa through pandanus war. Timbrah Village also in Karangasem Regency offering the roast suckling pig in the ceremony. Each householder obligates to offer roast suckling pig. If the village inhabit by 1000 householders means 1000 roast suckling pigs offer in the Pura Balai Agung. Meanwhile Kintamani area celebrates the ngusaba desa throught present the offering of the agricultural harvesting. This ceremony is known as ngusaba tegen.

\section{B. Previous Research on Bali Aga Villages}

Before being investigated by local researchers, the Bali Aga villages have apparently been studied by foreign researchers from the pre-independence era to the present. One researcher is Gregor Krause in 1912, where Krause initially worked for the Dutch East Indies government. Krause's research was published in the book of Bali 1912. This book describes the social and cultural life of the Balinese people in the Bangli area, which Kintamani one of sub-district in it. Other artists and researchers also follows the Krause's research, they are Margaret Mead and Gregory Bateson who examined from 1936 to 1939 in the village of Bayung Gede in Bangli Regency. Mead and Bateson's research is more anthropological according to their field of science background. Further, Covarrubias examines traditional villages with an emphasis on traditional Balinese architecture in 1974. Thomas Reuter focuses on his research in 2002 on the Bali Aga villages associated with the Bintang Danu, namely villages around Lake Batur and the Kintamani hills such as Sukawana Village, Kintamani Village, and Pinggan Village.

Local researchers then increasingly focused on the documentation of the Bali Aga villages, including Bali Provincial Public Works Office in 1988/1989, Runa in 2009, and Dwijendra in 2011. The Public Works of Bali Province had carried out an inventory of 38 Bali Aga villages. In the 1980s, Carole Muller had traveled in 25 Bali Aga villages and documented village photos in 2011. Based on the previous research studies and Bali Regional Regulations in 2009 then Yudantini (2015) concluded and sum up that there 62 Bali Aga villages extant and located over seven regencies in Bali Province. The 62 Bali Aga villages are shown in Table I. There are 12 villages in Karangasem Regency, 14 villages in 
Based on geographical position, Kintamani Sub-district boundaries by Buleleng Regency to the North; Karangasem Regency to the East; Buleleng Regency and Badung Regency to the West; and Bangli Sub-district and Gianyar Regency to the South. The population in Kintamani Sub-district in 2018 was $41.91 \%$ or 94.85 thousand people with a population density of 255.66 people per $\mathrm{km}^{2}$. Kintamani Sub-district consists of 48 administrative villages [6], however there are only 19 villages can be categorised as Bali Aga. Meanwhile in total Bangli Regency has 25 Bali Aga villages [1] (Table 2). Table II shows that Sukawana Village, Trunyan Village and Songan A Village have the most extensive areas, there are $33.61 \mathrm{~km}^{2}, 19.63 \mathrm{~km}^{2}$ and $17.01 \mathrm{~km}^{2}$ respectively. Figure 1 illustrates the distribution of Bali Aga villages in Bangli Regency.

TABLE II. BALI AGA VILlages DistribUtion IN BANGLI REGENCY

\begin{tabular}{|c|c|c|c|}
\hline No & Villages & Sub-district & Area $\left(\mathrm{km}^{2}\right)$ \\
\hline 1. & Bayung Gede & Kintamani & 10.24 \\
\hline 2. & Kedisan & Kintamani & 11.75 \\
\hline 3. & Songan A & Kintamani & 17.01 \\
\hline 4. & Songan B & Kintamani & 11.88 \\
\hline 5. & Trunyan & Kintamani & 19.63 \\
\hline 6. & Buahan & Kintamani & 14.23 \\
\hline 7. & Sekardadi & Kintamani & 8.40 \\
\hline 8. & Abangbatudinding & Kintamani & 14.33 \\
\hline 9. & Suter & Kintamani & 12.56 \\
\hline 10. & Satra & Kintamani & 11.63 \\
\hline 11. & Sukawana & Kintamani & 33.61 \\
\hline 12. & Catur & Kintamani & 7.56 \\
\hline 13. & Belantih & Kintamani & 9.05 \\
\hline 14. & Blandingan & Kintamani & 6.00 \\
\hline 15. & Pinggan & Kintamani & 16.53 \\
\hline 16. & Batur Utara & Kintamani & 3.36 \\
\hline 17. & Batur Selatan & Kintamani & 13.86 \\
\hline 18. & Batur Tengah & Kintamani & 4.74 \\
\hline 19. & Kintamani & Kintamani & 15.13 \\
\hline 20. & Pengotan & Bangli & 9.80 \\
\hline 21. & Kayubihi & Bangli & 9.46 \\
\hline 22. & Palaktiying (Landih) & Bangli & 6.33 \\
\hline 23. & Penglipuran & Bangli & 4.42 \\
\hline 24. & Pengiangan & Susut & 4.07 \\
\hline 25. & Yangapi & Tembuku & 14.32 \\
\hline & \multicolumn{2}{|r|}{ TOTAL } & 289.91 \\
\hline
\end{tabular}

Source: BPS Kabupaten Bangli, 2018

Kintamani Sub-district is one of the districts in Bangli Regency which has an area of $366.92 \mathrm{~km}^{2}$. Kintamani Subdistrict land use in 2017 consists of rice fields (110 hectares), plantations $(6,201.6$ hectares $)$, dry farm $(15,113.1$ hectares $)$, community forests (1,602 hectares), State forests $(9,341.3$ hectares), and non-agriculture land including roads, settlements, offices, rivers and others (4,324 hectares) [6]. 
Agung Temple. In this case, the saing nembelas (kiwa-tengen

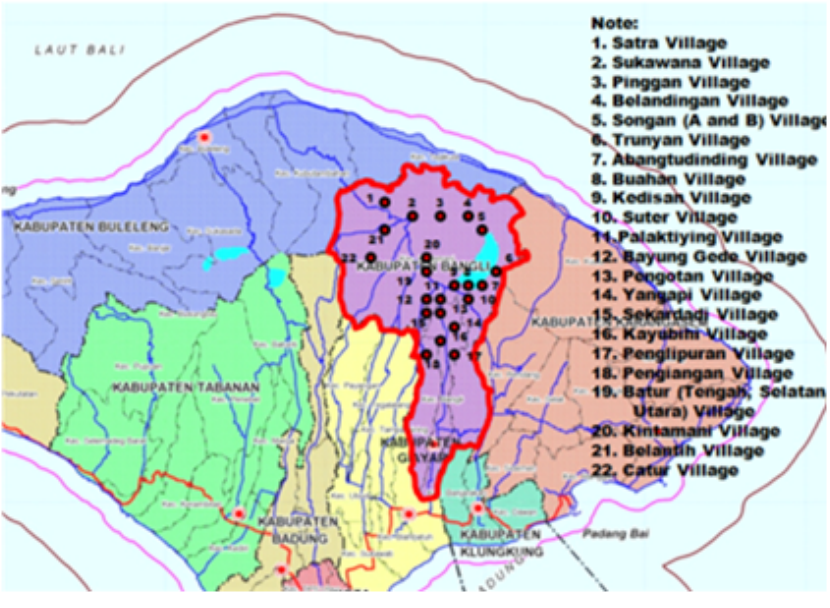

Fig. 1. Bali Aga villages mapping in Bangli Regency [1].

\section{B. Intangible Aspect of Study Case's Bali Aga Villages in Kintamani}

The intangible aspects are related to the socio-culture of the villages. In the study case, Suter and Abangbatudinding villages are located closely in one area (Figure 2 and 3 ). They are all embraced Hindu Religion. The villages are tied together to temples, there are Kahyangan Tiga temples (three villages temples including Bale Agung Temple, Puseh Temple, and Dalem Temple), 1 subak (irrigation) temple and 1 other temple such as Dadia or Kawitan Temple (a clan temple). In most villages, Bale Agung Temple (Pura Desa) is located in the center or core and as an orientation of village patterns that tends to be linear. The religious ceremonies in the village's temples are led by the Kubayan (elders) as it is traditional governance called ulu apad system.
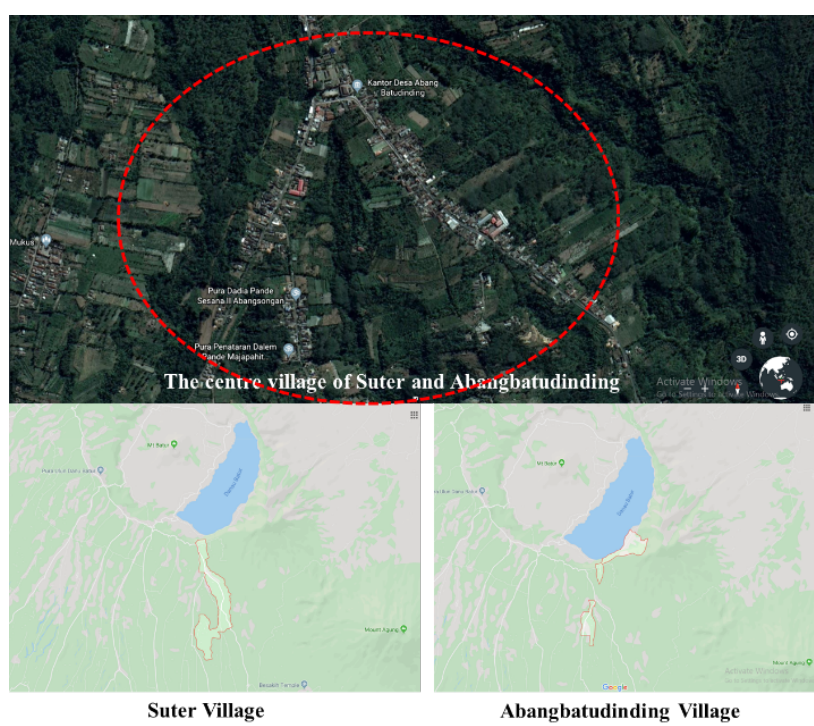

Fig. 2. Suter and Abangbatudindidng villages boundaries (Source: Google Earth and Google Maps, accessed November 8, 2019)

Suter and Abangbatudinding villages adopts a traditional government system called Apad or Ulu Apad, named as struktur tegak or struktur keduluan (elders system). Traditionally, the ulu apad has a total of 18 members that called saing nembelas. The saing nembelas divided into 9 people are seated in the right position and other 9 people in the left position when the traditional ceremony is held in the Balai or right-left is equal in number). The saing nembelas in total consists of Jero Kubayan (2 people), Jero Singgukan (2 people), Jero Catu (2 people), Jero Balung (4 people), Jero cacar (4 people), and jero juk (4 people) so that the total number of members is eighteen (18) people. The administrative governance system called pengalang that consists of Jero Mekel as the village leader, Jero Bendesa, Jero penyarikan and Jero pemangku. The administrative leaders work together to implement the programs in the village.

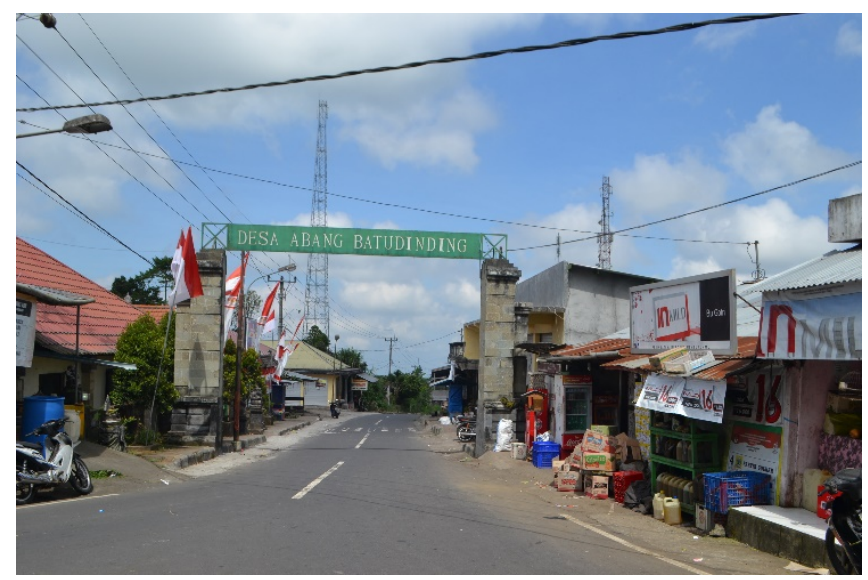

Fig. 3. Abangbatudindidng Village's entrance.

Suter and Abangbatudinding villages implement biye tanem of mass cremation (Figure 4 ) that held every 4 or 5 years. The cemetery is distinguished for public and for infants (rare). The grave was distinguished for infants is located in the downstream (teben) of the cemetery, and for common people is located in upstream ( $h u l u$ ) of the cemetery. The mass cremation is carried out at level of dadia (clan), which funded by the village. The people in Suter and Abangbatudinding villages are also adopt nyineb wangsa (hiding their castes), so they do not use noble's name in their name.

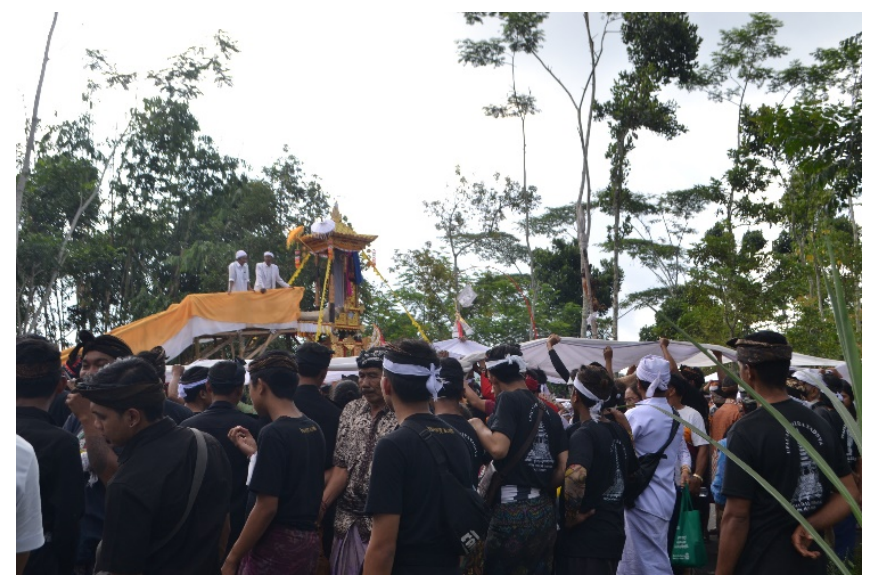

Fig. 4. A process of mass cremation in Suter Village.

The ngusaba (annual festival) in Suter and Abangbatudinding villages called ngusaba tegen that held the Balai Agung Temple. The ngusaba tegen is a ceremony to offer thankfulness to the ancestors for the wealthiest of prosperity and fertility. In this festival, the villager obligate to provide three offerings (tegenan). First tegenan is for the ancestors who have already been cremated (ngaben), second tegenan for the ancestors who not cremated yet, and the third 
called sakaroras in one unit housing (Figure 7) that inhabitant tegenan for the death infants. These tegenan are carried out in a day that starting from the lowest i.e. the death infants, ancestors who not cremated yet, and been cremated. The first tegenan for the infants will celebrate and offer in the front of the entrance of the each house, the second tegenan is presented in Puseh Temple, and the third tegenan is carried out at Balai Agung Temple (Pura Desa).

The villages of Suter and Abangbatudinding celebrate mass wedding ceremonies for the second marriage ceremony. The first wedding ceremony (the biokaonan) is held in each house. The second marriage ceremony (bakti jauman) held in Bale Agung Temple (Pura Desa). In fact the village office subsidies mass wedding ceremony due to the second marriage more expensive for the ceremony. According the the village's leader, there are 8 to 10 couples joint the mass wedding ceremony. The second marriage is also called pekandelan ceremony that is offering a bakti kelaci (klaci) in the form of a small pig. If the married couple is original from the same village (krama uwedan), thus they should to bring and offer two pigs as klaci. Meanwhile if the bride or the groom comes from other village or from outside the village, so they bring and offer one pig. In the past, the pork offerings slaughtered and the meat distribute to the villager as a notification that someone carry out a marriage ceremony. But nowadays, the village do not distribute the meat since the year of 2002. The pig offerings (kelaci) are handed over to the village to be cashed in and become village treasury and the village can use it to support the village program.

\section{Tangible Aspect of Bali Aga Villages in Kintamani}

Most Bali Aga village's settlement pattern face in a linear pattern due to the topographical of the village. Suter and Abangbatudinding villages have a linear pattern for the settlement composition (Figure 5 and 6). The village's orientation is at the Bale Agung Temple for its main direction to the kaja/North or utama mandala as a sacred zone in a village pattern.

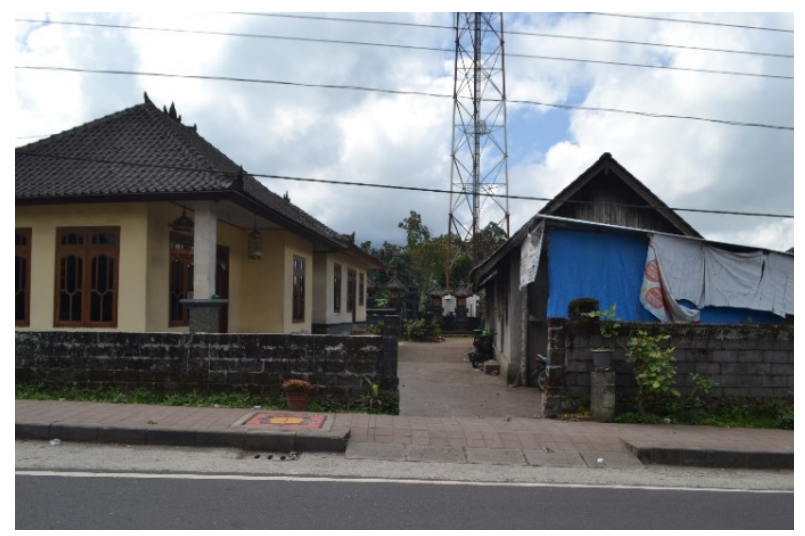

Fig. 5. A linear pattern in Suter Village

In most Bali Aga villages, one housing unit consists of several houses with a linear pattern. There are 5 to 10 houses in one unit housing and most of the population is not in one kinship. The house are open and there are no borders or fences between neighbors. These traditional values can be learned that people have a good relationship to trust each other. This is also for security in the village which involves everyone in control and monitoring the village environment. However, in current time, Suter Villages has few traditional houses in one unit housing. There are only one or two traditional houses by the father and his son who married. Most houses in the centre village have been changed into modern style (Figure 5).

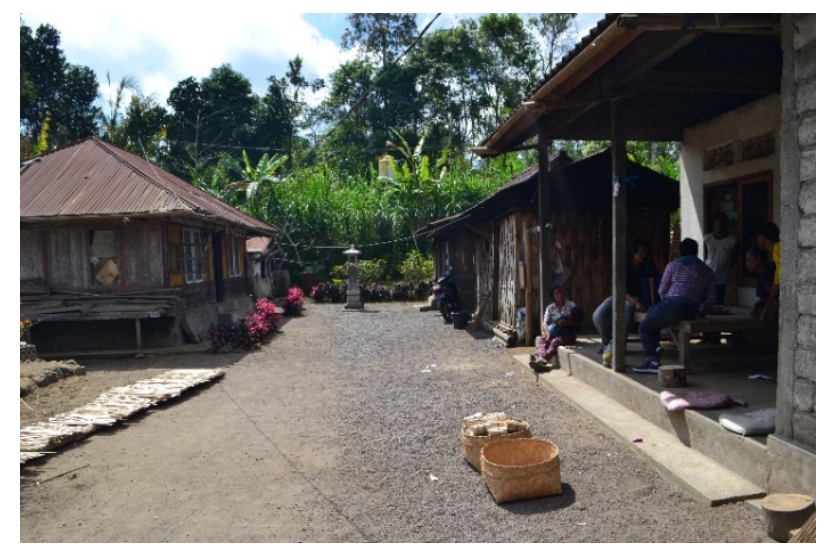

Fig. 6. A linear pattern in Suter Village

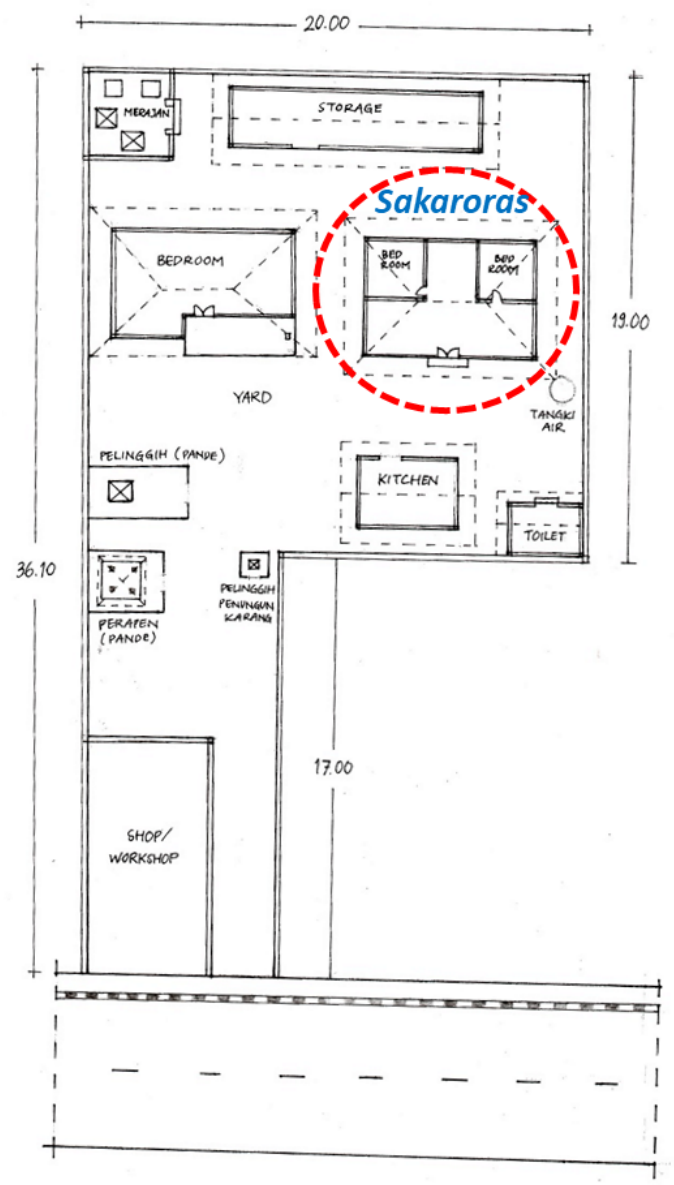

Fig. 7. The sakaroras in one unit housing in Suter Village (the house of Ketut Redita, 35 years old).

The traditional houses are called tampul roras or sakaroras. This traditional houses can be found far away from the inner village. They are located in the farms, where the villager built the sakararos in their new location of the farms. A traditional house of sakaroras consists of 4 functions, including kitchen (punapi), bedroom, shrine (pelangkiran) or holy room and small terrace or stair. The house has a simple function as a residence where people carry out their activities 
in one place in their house except for livelihood. In some houses there is no kitchen inside the sakaroras because they moved the kitchen to another place in the same yard (Figure 7). The kitchen room as a place to cook daily food, the bedroom as a place for rest at night, a holy room as a worship place to the ancestors.
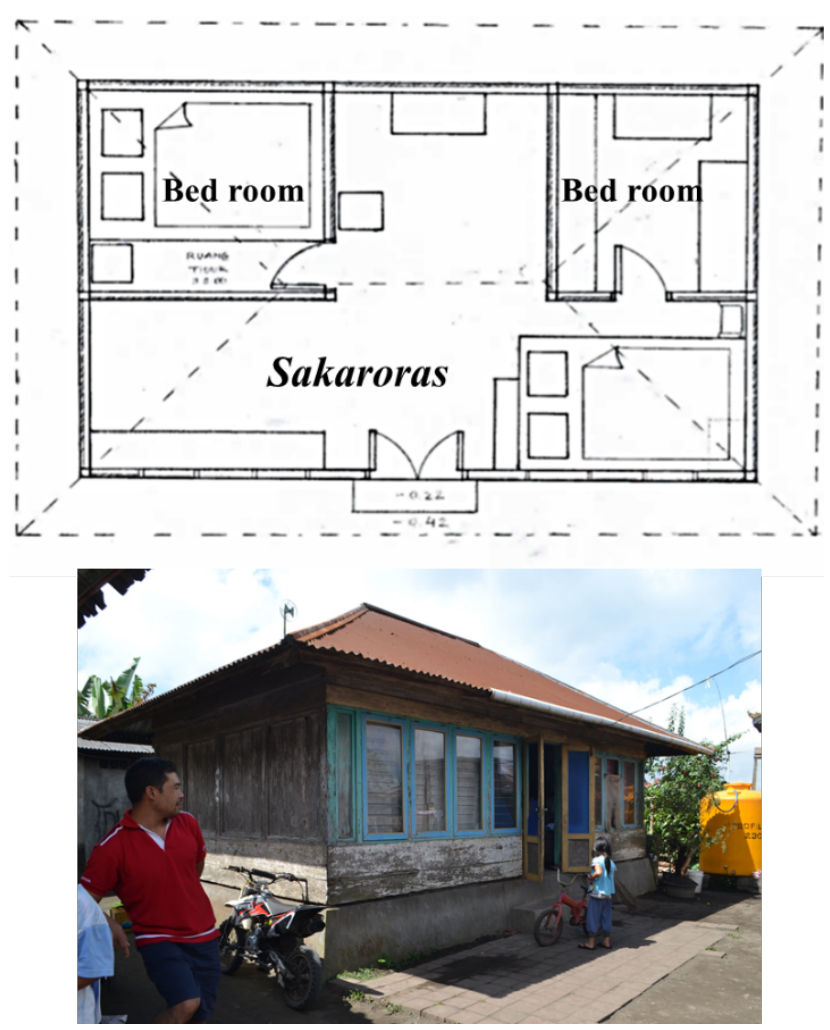

Fig. 8. Lay out plan and elevation of sakaroras in Suter Village (the house of Ketut Redita, 35 years old).

The sakaroras in the village of Suter is also called board houses due to the construction use board for the wall and timber for the structure (Figure 8). The material for the roof is using zinc which zinc can absorb the heat during the day and released it in the night time into inside the room remembering Kintamani has cold weather than other area.

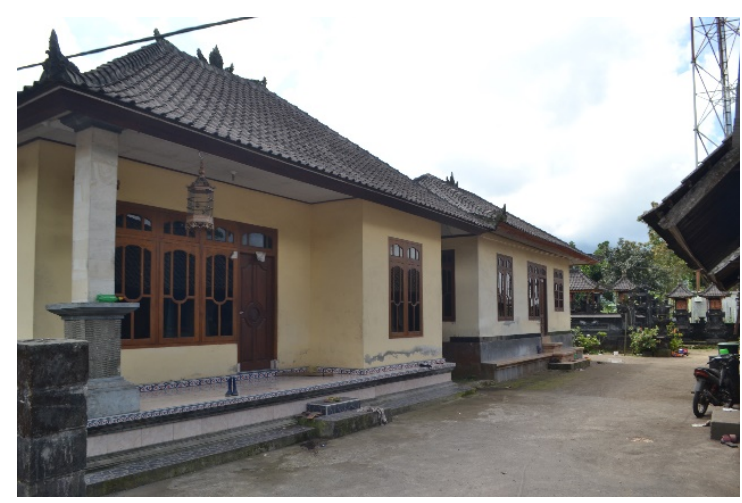

Fig. 9. A new appearance of houses in Abangbatudinding Village

Nowadays the existence of sakaroras is already difficult to find in the centre settlement in Suter Village. From the interview to the village leader, there are only five board houses or sakaroras that still conserved by the villagers. Most of the people change the traditional houses (sakaroras) into modern houses with modern structure and new material. Unfortunately, Abangbatudinding Village has no more sakaroras, although they still maintain the original tradition as Bali Aga village (Figure 9).

\section{CONCLUSION}

The conservation needs understanding and awareness of the people in the maintenance the heritage especially Balinese traditional architecture in Suter and Abangbatudinding. The village of Suter and Abangbatudinding historically they have close relationship and geography that all traditions and norms are same and implement in togetherness. This research concluded both villages, Suter and Abangbatudinding still conserve and implement the intangible of local values, norms, and tradition in daily life. Socially, the villagers still adopt and implement their original culture that inherited from the past. The people still believe and do not to deny the tradition. Suter and Abangbatudinding villages still apply the second marriage in few weeks or months after the first marriage. They strongly believe that if they do not obey the tradition, the undesirable things will happened into their life.

However, the tangible aspects especially the traditional houses start getting difficult to find in the both village. In general, the traditional houses in Suter and Abangbatudinding villages have change into modern appearance and using modern materials. Fortunately, Suter still conserves traditional houses of sakaroras or board houses although only few numbers can be found in the farm area. Only Suter have five sakaroras but it located far away from the centre of the village. This is due to increasing in globalisation that impact the life style of the people. This phenomenon cannot be avoided because influence of raising technology and communication to the rural area. As it is happened in Abangbatudinding that there have no sakaroras can be found in the village.

\section{ACKNOWLEDGMENT}

I owe my thanks to Udayana University who funded this research through DIPA PNBP Udayana University Fiscal Year 2019 in accordance with the Research Implementation Assignment Letter number 2483.2/UN 14.2.5.II/LT/2019, April 10, 2019. Acknowledgments are also addressed to research teams and students who have helped complete this research from the initial proposal to the final report.

\section{REFERENCES}

[1] N.M. Yudantini, "Bali Aga Cultural Landscape Challenges: Conserving the Balinese Traditional Landscape for Future Balinese Indigenous Villages (Bali Aga) and Communities," Doctorate Thesis. Deakin University-Australia, 2015.

[2] Dinas Pekerjaan Umum Propinsi Bali, "Inventarisasi Desa-Desa Tradisional Bali, Pemerintah Propinsi Daerah Tingkat I Bali," Dinas Pekerjaan Umum Propinsi Bali, Proyek Perencanaan Konservasi Lingkungan Desa (1988/1989), 1989.

[3] T.A. Reuter, "Custodians of the Sacred Mountains; Culture and Society in the Highlands of Bali," University of Hawaieci Press, Honolulu, 2002.

[4] M. Covarrubias, "Island of Bali," Kuala Lumpur: Oxford University Press/Indira, 1974.

[5] N.K.A. Dwijendra, "Arsitektur dan Kebudayaan Bali Kuno," Denpasar: Udayana University Press, 2009.

[6] BPS Kabupaten Bangli, "Kabupaten Bangli Dalam Angka 2018," Pemerintah Kabupaten Bangli, Propinsi Bali, 2018 